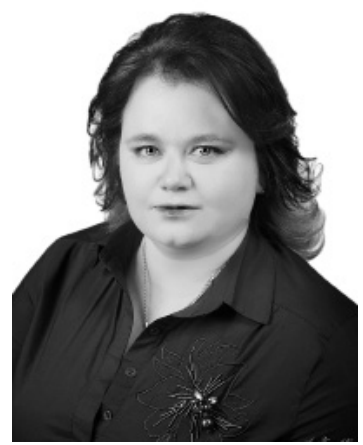

\title{
УЧАСНИКИ ОСВІДУВАННЯ ПІД ЧАС КРИМІНАЛЬНОГО ПРОВАДЖЕННЯ
}

\author{
ЦИЛЮРИК Інна Ігорівна - асистент кафедри кримінального права і \\ процесу Навчально-наукового інституту права, психології та інноваційної освіти \\ Національного університету «Львівська політехніка»
}

DOI:10.32782/LAW.2019.3.19

Статья посвящена анализу порядка проведения освидетельствования. Поскольку в законодательстве не четко определень чеели и задачи этого следственного (розъискного) действия. А это приводит к смешиванию указанныхх понятий в научной юридчческой литературе. Кроме этого, недостаточно определеннъими остаются видь освидетельствования и процессуальнъгй порядок их производства; нечетко сбормулировано в законе фактические основания его проведения; нет прочессуальной регламентации порядка осуществления принудительного освидетельствования. Это дает возможность органам досудебного расследования в правоприменении по своему усмотрению толковать некоторые положения закона, создает условия для необоснованного ограничения прав и свобод участников уголовного судопроизводства, привлеченньих к проведению следственнъх (розъскнъхх) действий.

Ключевъе слова: освидетельствование, следственнъие (розъскньие) действия, следователь, прокурор, понятьле, специалист, врач, судебно-медицинский эксперт.

\section{Вступ}

Однією з гарантій забезпечення прав i законних інтересів людини на досудовому розслідуванні є чітка та недвозначна процесуальна регламентація діяльності учасників кримінального провадження з метою дотримання процесуальної форми під час проведення слідчих (розшукових) й інших процесуальних дій, прийнятті проміжних і підсумкових процесуальних рішень. Натомість наявність колізій при здійсненні такої діяльності спричиняє появу супереч- ностей у правовому регулюванні процесуальних правовідносин і розбіжностей у теорії кримінального процесуального права та практичній діяльності 3 розслідування кримінальних правопорушень. Зазначене стосується деяких аспектів провадження слідчих (розшукових) дій, врегульованих КПК України, зокрема освідування.

13 квітня 2012 року Верховна Рада України прийняла Кримінальний процесуальний кодекс України, що набрав чинності 20 листопада 2012 року. Відповідно доч. 1 ст. 241 КПК, слідчий, прокурор здійснюе освідування підозрюваного, свідка або потерпілого для виявлення на їхньому тілі слідів кримінального правопорушення або особливих прикмет, якщо для цього не потрібно проводити судово-медичну експертизу.

Освідування - це самостійна слідча (розшукова) дія, що посідає чільне місце серед засобів збирання доказів у кримінальному провадженні. Якщо недооцінити важливість і значущість освідування та замінити його іншою слідчою (розшуковою) дією, наприклад, призначенням і проведенням судово-медичної експертизи, це може спричинити негативні наслідки, які у своїх роботах досліджували вчені. У разі призначення судово-медичної експертизи й постановки питань щодо тілесних ушкоджень на тілі підозрюваного, обвинуваченого або потерпілого, з огляду на те, що в подібних випадках питання щодо проведення освідування як самостійної слідчої (розшуко- 
вої) дії не постає, виникає загроза, що інші сліди злочину на тілі особи залишаться недослідженими. Це може призвести до втрати необхідних доказів, відновлення яких не завжди можливе.

\section{Постановка проблеми}

Законодавча регламентація у статті 241 КПК України порядку проведення освідування $\epsilon$ недосконалою, оскільки чітко не визначено мету і завдання цієї слідчої (розшукової) дії. А це призводить до змішування зазначених понять у науковій юридичній літературі. Крім цього, недостатньо визначеними залишаються види освідування та процесуальний порядок їх провадження; не чітко сформульовано в законі фактичні підстави його проведення; немає процесуальної регламентації порядку провадження примусового освідування. Це надає можливість органам досудового розслідування у правозастосуванні на власний розсуд тлумачити деякі положення закону, що створює умови для необгрунтованого обмеження прав і свобод учасників кримінального провадження, залучених до проведення слідчих (розшукових) дій.

\section{Аналіз останніх досліджень}

Питання мети та завдання освідування як слідчої (розшукової) дії досліджували у своїх працях О. А. Борідько, В. В. Вапнярчук, Ю. М. Грошевий, О. В. Капліна, Л. М. Аобойко, Б. Е. Аук'янчиков, E. Д. Аук'янчиков, К. О. Чаплинський, А. П. Черненко, О. Г. Шило та багато інших. Однак численні дослідження цього питання не забезпечили формування єдиної позиції та його єдиного тлумачення.

Метою цієї статті висвітлення особливостей проведення освідування особами, які мають на це право.

\section{Виклад основного матеріалу}

Залежно від виду освідування, частиною 7 статті 223, частиною 2 статті 241 КПК України під час його проведення передбачено участь певних осіб в обов'язковому порядку та їх можлива участь на розсуд слідчого.
Особами, які здійснюють і беруть участь в освідуванні, за КПК України є слідчий, прокурор за участю судово-медичного експерта або лікаря, поняті. Визначення осіб, які мають проводити освідування, залежить від виду цієї слідчої (розшукової) дії. Таким чином, в особи, яка підлягала освідуванню, не було законної підстави вимагати відводу слідчого від участі в проведенні цієї слідчої діï.

Водночас слід визнати за доцільне за наявності клопотання підозрюваного про відвід слідчого доручити проведення освідування лікарю. Слідчий міг би не бути присутнім під час освідування й 3 особистої ініціативи, якщо це зумовлено морально-етичними міркуваннями. Однак як він може прийняти рішення щодо своєї участі в освідуванні, законодавець чітко не визначив. У пункті 1 частини 2 статті 39 КПК України лише зазначено про повноваження керівника органу досудового розслідування у випадках здійснення досудового розслідування слідчою групою визначати старшого цієї групи, який керуватиме діями інших слідчих.

На наш погляд, у проведенні освідування повною мірою може брати участь також учасник, який представляє інтереси певної особи, що є гарантією дотримання прав i законних інтересів освідування. Зокрема, під час проведення освідування неповнолітнього або недієздатного чи обмежено дієздатного має бути присутнім їх законний представник. Участь цієї особи є необхідною 3 урахуванням дачі можливих пояснень 3 приводу наявності яких-небудь особливих прикмет, ушкоджень, слідів тощо.

У процесі освідування для виявлення, фіксації та вилучення особливих прикмет виникає потреба застосовувати спеціальні знання. Мета залучення спеціаліста до участі в слідчих (розшукових) діях - розширення практичних можливостей слідчого у кваліфікованому проведенні певних дій, досягнення при цьому повного, об'єктивного та всебічного з'ясування обставин події, яку розслідують, сприяння своїми професійними знаннями і навичками виявленню, фіксації та вилученню доказів. Особливістю цієї форми застосування спеціальних знань 


\section{Кримінальне право, кримінальний процес та криміналістика}

є те, що закон розрізняє два види їх участі під час проведення слідчих (розшукових) дій - обов'язкове та факультативне [1].

Якщо в слідчого виникають труднощі під час самостійного проведення освідування у зв'язку з незнанням медичних термінів і загроза неправильного описання виявлених слідів кримінального правопорушення чи особливих прикмет, то саме в цих випадках доцільним є його звернення до прокурора для призначення судово-медичного освідування.

Беручи участь у проведенні освідування, лікар як спеціаліст має впливати на виявлення та фіксацію слідів злочину й особливих прикмет, зокрема: акцентує увагу слідчого на ті особливості тіла, які він не помітив (наприклад, наявність рубця або пігментної ділянки шкіри); дає характеристику тілесного ушкодження (садно, синець, рана); допомагає правильно описати виявлені ушкодження тіла, точно вказавши їх локалізацію відповідно до анатомічної будови людини; допомагає точно визначити форму ушкодження, його розміри, властивості, колір; здійснює дії, безпосередньо спрямовані на вилучення виявлених слідів злочину (крові, сперми); проводить консультації слідчому щодо обставин, за якими він спостерігає 3 позиції медичних знань, роз'яснює причини, їх значення, наслідки виявлення ушкоджень та інших слідів злочину, а також деяких видів особливих прикмет; висловлює припущення про час, механізм виникнення виявлених слідів, а також про можливе розміщення потерпілого й злочинця в момент утворення на тілі освідуваної особи тілесних ушкоджень; дає пояснення по суті проведення ним дій, спрямованих на встановлення, фіксацію й вилучення слідів злочину чи ті сліди й пошкодження, пов'язані із вчиненням злочину, які може бути виявлено на інших ділянках тіла або на місці події [2].

Особливість статусу лікаря як спеціаліста полягає також у тому, що він має визначити характер дій, які можуть становити небезпеку для здоров'я освідуваної особи та проведення яких заборонено законом. Водночас лікар управі вимагати занесення у протокол слідчої (розшукової) дії сво- їх заперечень з приводу провадження тих діянь, які з погляду медицини небезпечні для здоров’я цієї особи [3].

Важливою є також і та обставина, що почуття сорому в людини не має виникати під час огляду їі тіла лікарем чи експертом, тому закон не вимагає, щоб ці особи були однієї статі з освідуваним [4].

Кримінальне процесуальне законодавство України, крім лікаря, не передбачає участі в освідуванні іншого спеціаліста. Водночас у практичній діяльності мають місце випадки запрошення до участі в освідуванні інших осіб, які володіють спеціальними знаннями. Такими знаннями у кримінальному провадженні вважають знання та навички, отримані внаслідок фахової освіти та практичної діяльності в будь-якій галузі науки, техніки, мистецтва чи ремесла, які використовують визначені законом учасники процесу в межах наданих кожному 3 них повноважень для виконання за певною процедурою процесуальних завдань [4].

Не менш актуальною є проблема участі під час проведення освідування понятих, які своїми підписами підтверджують отримані результати цієї слідчої (розшукової) діï.

Приймаючи рішення про залучення понятих до участі в проведенні освідування, слід керуватися етичними міркуваннями, на чому слушно наголошують як науковці, так і практичні працівники. 3 почуття сором'язливості не кожна особа бажає, щоб під час огляду ії тіла були присутні сторонні особи. Не заглиблюючись у сутність цього питання, зазначимо лише, що одним 3 випадків запрошення понятих 6 необхідність запобігти можливим неправомірним скаргам на дії слідчого. Для вирішення цього питання слід врахувати пропозицію В. Г. Дрозд, яка цілком слушно зазначає, що запрошення до участі понятих доцільно погоджувати 3 особою, 3 огляду на етичні міркування, однак остаточне рішення приймає слідчий [5]. Необхідно усвідомлювати, що особі, яка добровільно погодилася на освідування, може бути неприємно, щоб iii оголене тіло або його окремі частини оглядав не лише слідчий, а ще й поняті, які є запрошеними сторонніми особами. У 
випадках, коли в освідуванні бере участь судово-медичний експерт або лікар, немає необхідності в залученні понятих. В інших випадках це право слідчого, яким він користується залежно від слідчої ситуації, що склалася на кожний конкретний момент розслідування.

Якщо слідчий вирішив запросити понятих, то ними не повинні бути сусіди, знайомі, колеги тощо. У цьому разі освідувана особа має право клопотати про відвід понятих і таке клопотання, на наш погляд, має бути задоволено. Для ще більш значного забезпечення гарантій невтручання в особисте та сімейне життя під час проведення освідування необхідно закріпити у КПК України право освідуваного заявляти відвід будь-якій особі, яка бере участь у проведенні цієї слідчої (розшукової) дії, якщо є обгрунтовані підстави вважати, що такою особою можуть бути розголошені відомості щодо особистого та сімейного життя.

Коло суб'єктів кримінального провадження, які здійснюють освідування чи беруть у ньому участь, за ступенем обов'язковості можна умовно поділити на обов'язкових та факультативних. Проте стійкого розподілу за цими критеріями учасників проведення саме освідування, враховуючи ії специфіку, немає.

у залежності від виду освідування, можна виокремити такі види суб'єктів. Під час проведення слідчого освідування обов'язковим учасником слідчої (розшукової) дії є посадова особа - слідчий, прокурор, які не завжди є однією особою, що проводить цю процесуальну дію у кримінальному провадженні. Зокрема, відповідно до частини 2 статті 36 КПК України, прокурор здійснює не досудове розслідування, а процесуальне керівництво за кримінальним провадженням. Отже, посадовою особою, що розслідує злочин, є слідчий, а посадовою особою, яка проводить освідування, може бути прокурор.

Беззаперечним є те, що факультативними учасниками під час здійснення слідчого освідування є судово-медичний експерт або лікар (частина 2 статті 241 КПК України), а також спеціаліст ( ст.71 КПК України). Участь спеціаліста в досудовому розсліду- ванні зводиться до надання безпосередньої технічної допомоги. На наше переконання, перелік факультативних учасників освідування в статті 241 КПК України необхідно розширити та запропонувати законодавчо закріпити можливість участі в проведенні освідування й інших спеціалістів 3 різних галузей науки і техніки, про що вже зазначалося раніше.

Під час медичного освідування як самостійного виду цієї слідчої (розшукової) дії, навпаки, обов'язковим її суб'єктом, про що зазначено в ч. 2 ст. 241 КПК України, є лікар. Водночас необхідно з'ясувати, чому лише лікар може провести освідування особи, пов'язане з оголенням ії тіла. На наш погляд, законодавець учиняє непослідовно, не зазначивши судово-медичного експерта серед спеціалістів, які також можуть здійснити освідування особи, пов'язане, зокрема, з ії оголенням. Судово-медичний експерт - це спеціаліст, що має вищу медичну освіту, стаж і досвід роботи саме в галузі судової медицини. Більше того, судово-медичний експерт якісніше встановить на тілі особи особливі прикмети та сліди злочину, пов'язані з розслідуваною подією, на відміну від лікаря, для якого медичне освідування особи належить до кола додаткових, а не головних обов'язків.

Віднесення слідчого, прокурора до певної групи суб'єктів $\epsilon$ питанням суперечливим. У законодавстві України передбачено лише одне обмеження щодо заборони присутності цих посадових осіб під час проведення судово-медичного освідування - оголення освідуваної особи. Отже, на нашу думку, обов'язковими учасниками проведення судово-медичного освідування є як судово-медичний експерт, лікар, так i слідчий, прокурор, за винятком проведення цієї слідчої (розшукової) дії, що супроводжується оголенням освідуваної особи.

Незалежно від виду освідування, у кримінальному процесуальному законодавстві України передбачено участь понятих: за КПК України - поняті мають обов'язково бути присутніми під час проведення низки слідчих (розшукових) дій, зокрема освідування (ч. 7 ст. 223 КПК України). На нашу думку, підхід щодо участі понятих, визна- 


\section{Кримінальне право, кримінальний процес та криміналістика}

чений у КПК України, виключає ситуації, коли слідчий на свій розсуд визначає склад учасників проведення освідування, є додатковою гарантією забезпечення прав освідуваної особи, дотримання законності під час освідування.

Відповідно до чинного КПК України, коло факультативних учасників освідування розширене двома категоріями осіб:

1) особи, права та законні інтереси яких може бути обмежено або порушено;

2) особи, які ініціювали проведення освідування, та їх захисники чи представники.

У ч. 2 ст. 223 КПК України зазначено, що під час проведення освідування слідчий, прокурор уживають належних заходів для забезпечення присутності під час проведення слідчої (розшукової) дії особам, які беруть у ній участь, роз'яснюють їх права і обов'язки, передбачені КПК України, а також відповідальність, установлену законом. Якщо особа є учасником кримінального провадження й має визначений процесуальний статус, їй роз'яснюють відповідні цьому статусу прав та обов'язки.

В інших ситуаціях необхідно визначити процесуальний статус особи, права та законні інтереси якої може бути обмежено чи порушено. Наприклад, під час освідування особи, яка підозрюється у вчиненні злочину, з метою встановлення особливих прикмет, що супроводжуються їі оголенням, може бути порушено право освідуваної особи на невтручання у їі приватне життя.

Відповідно до ч. 6 ст. 223 КПК України, слідча (розшукова) дія, яку здійснюють за клопотанням сторони захисту, потерпілого, проводять за участю особи, яка її ініціювала, та (або) їі захисника чи представника, крім випадків, коли з огляду на специфіку слідчої (розшукової) дії це неможливо або ця особа письмово відмовилась від участі в ній. Під час проведення цієї слідчої (розшукової) дії присутні особи, які їі ініціювали, мають право ставити питання, висловлювати свої пропозиції, зауваження та заперечення щодо порядку проведення відповідної слідчої (розшукової) дії, що обов’язково заносять до протоколу.
Із цього положення ми бачимо, що право ініціювати проведення освідування мають потерпілий i його представник, а також згідно 3 п. 19 ч. 1 ст. 3 КПК України, підозрюваний, обвинувачений (підсудний), засуджений, виправданий, особа, стосовно якої передбачено застосування примусових заходів медичного чи виховного характеру або вирішували питання про їх застосування, їхні захисники та законні представники.

Таким чином, учасників освідування можна розділити на обов'язкових і факультативних залежно від процесуальної форми кримінального провадження й виду освідування, передбаченого процесуальним законом.

\section{Висновки}

Враховуючи усе вищевикладене, ми дійшли висновку, що за КПК України під час проведення слідчого освідування обов'язковими учасниками є посадові особи - слідчий чи прокурор, які безпосередньо його проводять, освідувана особа, поняті. До факультативних учасників належать судово-медичний експерт, лікар, інші спеціалісти, а також особи, права та законні інтереси яких може бути обмежено чи порушено, та особи, які ініціювали проведення цієї слідчої (розшукової) дії. Під час проведення судово-медичного освідування обов'язкові учасники це судово-медичний експерт чи лікар, освідувана особа, а також слідчий, прокурор, поняті. Факультативними учасниками проведення цього виду освідування можуть бути спеціалісти, а також особи, права та законні інтереси яких може бути обмежено або порушено, та особи, які ініціювали проведення цієї слідчої (розшукової) дії.

\section{入ітература}

1. Букаев Н. Проблемы производства освидетельствования как следственного действия по УПК РФ. Закон и жизнъ. 2004. № 10 . С.13

2. Торбин Ю. Г. Уголовно-процессуальнъле и криминалистические проблемъ освидетельствования. URL: http://k-press.ru/bh/2003/2/ torbin2/torbin2.asp 


\section{АНОТАЦІЯ}

Законодавча регламентація у статті 241 КПК України порядку проведення освідування є недосконалою, оскільки чітко не визначено мету $i$ завдання иієї слідиӧ (розшукової) дї̈. A цее призводить до змішування зазначених понять у науковій юридичній літературі. Крім иъього, недостатнъо визначеними залишаються види освідування та процесуальний порядок їх провадження; не чітко сбормульовано в законі фактичні підстави його проведення; немає процесуальної регламентациї порядку провадження примусового освідування. Це надає можливість органам досудового розслідування у правозастосуванні на власний розсуд тлумачити деякі положення закону, що створюе умови для необгрунтованого обмеження прав $i$ свобод учасників кримінального провадження, залучених до проведення слідчих (розшукових) diü.

Ключові слова: освідування, слідчі (розшукові) дї, слідчий, прокурор, поняті, спеиіаліст, лікар, судово-медичний експерт.

3. Садова Т. В. Обмеження прав $i$ свобод у кримінальному судочинстві України та держав англо-американсъкоӥ правової системи в контексті міжнародних стандартів : монографія. Івано-Франківськ, Надвірна : ЗАТ «Надвірнянська друкарня», 2011. С. 150.

4. Курдюков В. В. Теоретичні засади та критерії обов'язкового призначення судових експертиз в кримінальному прочесі україни : автореф. дис. на здобуття ступеня канд. юрид. наук : спец. 12.00.09. К., 2009. С. 9.

5. Дрозд В. Г. Організаиійні $і$ тактичні аспекти розслідування умисних тяжких тілесних ушкодженъ: автореф. дис. на здобуття ступеня канд. юрид. наук : спец. 12.00.09. К. 2009. С.10.
One of the guarantees of ensuring the rights and legitimate interests in the pre-trial investigation is clear and unambiguous procedural regulation of activity of participants of criminal proceedings with the aim of observance procedural forms during the conduct of investigative (search) and other procedural actions, acceptance of intermediate and final procedural decisions. But the existence of conflicts in the implementation of such activities was the emergence of contradictions in the legal regulation and legal proceedings, disputes in the theory of criminal procedural law and practice for the investigation of criminal offences. The marked touches some aspects of investigative (search) actions regulated by the Criminal procedure code of Ukraine, in particular examination.

Examination is an independent investigative (search) activity that occupies a prominent place among the ways of gathering evidence in criminal proceeding. If underestimate the importance and significance of examination and replace it with another investigative (search) action, for example, the appointment and conduct of forensic-medical examination, it may lead to negative consequences, which were examined by scientists in their works. In the case of appointment of a forensic-medical examination and ask questions regarding injuries on the body of the suspect, the accused or the victim, given that in such cases the question of holding the examination as an independent investigative (search) actions does not occur, there is a threat that other traces of the crime on the human body remains unexplored. This may result the loss of necessary evidence, the recovery of which is not always possible.

Depending on the kind of examination, part 7 of article 223, part 2 of article 241 of Criminal procedure code of Ukraine during it realization is envisaged participating of certain persons in the obligatory order and their possible participation at the discretion of the investigator

Individuals who provide and take part in the examination by the Criminal procedure code of Ukraine is the investigator, prosecutor with the participation of a forensic-medical expert or doctor, concepts. The definition of persons who should conduct the examination depends on the kind of this in vestigatory (search) actions. Thus, persons who were subject to examination, there was no legitimate reason to demand the removal of the investigator from participation in the conduct of this investigation.

Participants of examination can be divided into compulsory and optional, depending on the procedural form of criminal proceedings and examination under the procedural law.

Key words: education, investigators (investigative) actions, investigator, prosecutor, notions, specialist, doctor, forensic expert. 